\title{
IMPROVING STUDENTS' SPEAKING SKILL THROUGH DEBATE TECHNIQUE AT SMK SWASTA DHARMA BAKTI MEDAN
}

\author{
Mesda Pitrina Nainggolan \\ Catholic University of Saint Thomas North Sumatera
}

\begin{abstract}
Speaking is important to be learnt because speaking is the way to communicate with other people in order to deliver opinion and express idea. That means there must be at least two people in speaking, otherwise it is not called speaking. Speaking is the primary aspect of learning a language because the final goal of language learning is communication. This study is Classroom Action Research in which the writer employs debate technique in teaching speaking. The teaching process was carried out in two cycles. The data consist of observation sheet and test. The data from the observation that have been taken from every cycle are analyzed descriptively, while the data from test are analyzed quantitatively. The result of this study shows that using debate technique can improve students' speaking skill. This is proven by students' test score that improved in each test. In the pre-test, the students' average score is 66.2. While in the formative test cycle I, the students' average score is 67.6, and in the post-test cycle II, the students' average score is 76.3. That means the debate technique can improve the students' speaking skill significantly.
\end{abstract}

Keywords: speaking skill, debate technique, Classroom Action Research

\section{INTRODUCTION}

Basically language is spoken. At first, man learns to listen and then speak, and later he learns other skills such as reading and writing. Therefore, many people can speak a language but they cannot read or write it. Such people are called illiterate. Although they are illiterate they can speak, and this is to prove that language is spoken.

The final goal of learning a language is speaking. That means the students are expected to be able to speak that language at the end of the program. Speaking is one of the four basic skills in learning a language besides listening, reading, and writing. Speaking is the ability to express oneself in life situations, or the ability to express an idea fluently. It is also an interactive process of constructing meaning which involves producing, receiving and processing information. Fulcher (2003:23) states, "Speaking is the verbal use of language to communicate with others that in speaking there is a process of communication between a speaker and a listener". It is clear that speaking occurs between a speaker and a listener. That means there must be at least two people in speaking.

Wallace (1978:98) states, "Oral practice or speaking becomes meaningful to students when they give attention to what they are saying". Thus, the students can learn better on how to require the ability to converse or to express their ideas fluently with precise vocabularies and good or acceptable pronunciation and by s peaking students can say everything that they have in their mind. In fact, most of students are difficult to speak even though they have a lot of vocabularies. There are too many factors that make speaking difficult. The structure of the language, the sounds, the pronunciation, and many other differences between the students' language, and the target language make it difficult for the students. But it does not mean it cannot be achieved. On the contrary, it can be achieved when a serious effort is made.

The writer's observation toward the eleventh grade students of Accounting Section Class XI A of SMK Swasta Dharma Bakti Medan in the Academic Year of 2016/2017 showed that some of the students seldom speak in English with their friends. The writer found out that the students lack of practices, vocabularies, willing, and self-confidence. 
The writer observed that the students stopped speaking when they did not know what and how to say words in English. Some of the students tried to find out meanings of the English of the words by opening the dictionaries but some of them did not care at all. The writer interviewed three students namely SS, KS, and MK. The students said that they found many unfamiliar English words that caused them difficult in comprehending what the teacher said and responding to the teacher.

The writer also interviewed Mr. UB, the teacher of English at SMK Swasta Dharma Bakti Medan about the students' speaking skill. He said that the students' speaking skill is still low. It is average 60 and it is for all English skills. While the Minimum Mastery Criteria (Kriteria Ketuntasan Minimal / KKM) of English subject is 70, so to get the Minimum Mastery Criteria (Kriteria Ketuntasan Minimal / KKM), the teacher usually gives additional score. The students are difficult to speak in the English language because they lack of vocabularies, practices, and self-confidence.

Considering the gap between reality and expectation, the writer was interested in giving a probable solution. To learn English speaking skill, the teachers use many kinds of ways in order to make the students master the lesson. Various ways have been used as the methods of teaching and learning English to make it easier to be understood. Beginning from the traditional way by using traditional tools such as books, chalk, blackboard or whiteboard into the newer and modern tools such as real object, pictures, music, in focus, etc. But the ability of speaking of the students is not yet satisfactory. One of the modern techniques which is used in teaching speaking is debate technique. It is seen as an active learning process because students will learn more through a process in constructing and creating knowledge, working in a group and also sharing knowledge one another. Debate technique makes the students more active and enables them to communicate and give arguments in English, and also by this technique the students know the way how to speak well.

The writer chose this technique because some research findings have shown the good result of teaching speaking by using debate technique. The first research which had been done by Hery (2011) with the title "Improving Students' Speaking Skill through Debate Technique" showed a good result. He stated that students' speaking skill improved after debate technique was applied. The second research had been done by Somjai (2015) with the title "The Use of Debate Technique to Develop Students' Speaking Ability". He stated that the mean score of post-test is higher than the mean of pre-test in cycle I. The research finding showed that students' speaking skill progressed significantly after debate technique was applied. The third research has been done by Rubiati (2010) with the title "Improving Students' Speaking Skill through Debate Technique". She concluded that teaching speaking through debate technique is enjoyable. Students could improve their speaking skill after having been taught with debate technique. Therefore the writer wanted to apply the same technique to teach speaking skill to the eleventh grade students of Accounting Section Class XI A of SMK Swasta Dharma Bakti Medan in the Academic Year of 2016/2017. The writer wanted to describe the processes in applying debate technique and to prove that debate technique also gives good result to their speaking skill. According to Mulgrave (2004:64-83), there are three systems of debate. They are Asian Parliamentary Debate, British Parliamentary Debate, and Australasian Parliamentary Debate. The writer will use Australasian Parliamentary Debate, in order to improve students' speaking skill because this debate system is more suitable to be applied for Senior High School students.

This study is important to be conducted because if it is not conducted, teachers will not be able to know students' problems in speaking and how students have progressed in speaking, so the teachers will not get the feedback from the students. Meanwhile, if this study is conducted, it will give positive impact. This study will be useful for language teachers, so they are able to know how far students have improved in speaking. As a result, teacher will be 
able to develop a curriculum design and choose an appropriate treatment to help students in expressing their ideas in the English language orally.

Based on the background of the study, the writer was interested in conducting a research entitled 'Improving Students' Speaking Skill through Debate Technique at SMK Swasta Dharma Bakti Medan" with the eleventh grade students of Accounting Section Class XI A of SMK Swasta Dharma Bakti Medan in the Academic Year of 2016/2017 as the subject of the research.

\section{REVIEW OF LITERATURE}

\subsection{Speaking}

There are a number of views related to the concepts of speaking. Brown (2001:267) states "Speaking is an interactive process of constructing meaning that involves producing and receiving and processing information". Speaking is not as simple as process of producing sounds but the fact speaking is more complex. During the speaking process, the speaker will receive the information firstly, and then the brain works automatically to process the information and finally the speaker gets the stimulation to produce the language.

In this case, the process will end up by producing sentences which figure out the speaker's intended meaning. Speaking involves thinking about language and social skills. The speaker has to combine words into sentences and then the speaker has to choose a language style which is appropriate to the social context during the conversation. The reason for choosing the language style is because of the human's social context. The language used in hospital and office must be different in style because the style shows who the speaker is. For example:

Doctor: Good morning, what about this new patient?

Nurse: He got D.M (Diabetes Mellitus).

From the conversation above, we can see that the speakers are a doctor and a nurse. The conversation is taking place at a hospital.

\subsubsection{Speaking Skill}

Speaking skill is not separated from listening skill because the activity of speaking is done by two or more persons. Someone who does not have knowledge about the language, or who does not have communicative competence in language, will not be able to take part in speaking activities.

Brown (2001:267-269) states that there are five components generally recognized in analysis of the speech process. They are:

1) fluency: This can be defined as the ability to speak fluently. Fluency in speaking is the aim of many language learners. This fluency must be supported by grammatical knowledge of the language.

2) accuracy: It is needed by students to arrange a correct sentence in a conversation, or the students' ability to produce correct sentence by using correct grammar and vocabulary. The sentence is not only grammatically correct, but it should also be meaningfully acceptable. Example: My brother is pregnant. This sentence is grammatically correct but meaningfully unacceptable because "brother" is male, and is never pregnant according to his nature.

3) vocabulary: Someone cannot communicate effectively or express his ideas both orally and in written forms if he does not have sufficient vocabulary, vocabulary means the appropriate diction which is used in communication.

4) grammar: Grammar is the set of structural rules governing the composition of clause, phrases, and words in any given natural language. For example: He went to school yesterday.

5) pronunciation: Pronunciation is the way for students to produce clearer language when they speak. It deals with the phonological process that determines how sounds vary and pattern in language. This aspect needs practicing a lot because of sound difference between English and Indonesian pronunciation. 


\subsubsection{Elements of Speaking}

Many students have difficulties in speaking. Harmer (2007:263-264) states that there are many elements of speaking that must be mastered by students in order to be a good speaker. They are:

1) connected speech: Effective speaker of English need to be able not only to produce the individual phonemes of English, but also to use connected speech fluently. In connecting speech, sounds are modified, omitted, added, or weakened. Example: I must go (ai mAs gou), I have done it (aiv dAn it), Last night (lAs nait).

2) expressive devices: Native of English change the pitch and stress of particular parts of utterances, vary volume and speed, and show other physical and nonverbal means how they are feeling. The use of these devices contributes to the ability to convey meaning.

3) lexis and grammar: Spontaneous speech is marked by the use of number of common lexical phrases, especially in their performance of certain language function. Therefore teachers should supply variety of phrases for different functions, such as greeting, agreeing and disagreeing.

\subsubsection{Types of Classroom Speaking Performances}

According to Brown (2001:271-274), there are six categories of speaking performance. They are:

1) imitative: Imitation is carried out for the purpose for focusing on some particular element of language form. During the imitation activity, for example, the learners practice an intonation of a certain vowel sound. This kind of activity can be categorized as a drilling. Drills offer students an opportunity to listen and to repeat certain words orally. Example: feel-fill, peel-pill, pen-pan. 2) intensive: Intensive speaking focuses on the components of discourse including phonemes, words, intonation, discourse makers.

3) responsive: Responsive speaking concerns with the short stretches of teacher language designed to elicit immediate responses. In other words, short replies to teacher or student initiated questions or comments which are needed in responsive speaking. Example:

Teacher: What time did you get up this morning?

Student: 5.30 sir.

4) transactional (dialogue): Transactional language is an extended form of responsive language. Transactional language is carried out for the purpose of conveying or exchanging specific information, for example a conversation.

A: What is the main idea in this essay?

B: The United Nations should have more authority.

A: More authority than what?

B: Than it does right now.

A: What do you mean?

B: Well, for example, the United Nations should have the power to force a country like Iraq to destroy its nuclear weapons.

A: You do not think the United Nations has that power now?

B: Obviously not. Iraq is still manufacturing nuclear bombs.

5) interpersonal (dialogue): Interpersonal dialogue is carried out more for the purpose of maintaining the social relationships than for the transmission of facts and information. Interpersonal dialogue is not just about what is actually said, but how it is said and the nonverbal massages expressed through the gesture, tone of voice, and body language. For example:

Amy: Hi, Bob, how is it going?

Bob: Oh, just so-so

Amy: Not a great weekend, huh?

Bob: Well, far be it from me to criticize, but I'm pretty miffed about last week.

Amy: What are you talking about?

Bob: I think you know perfectly well what I'm talking about. 
Amy: Oh, that. How come you get so bent out of shape over something like that? Bob: Well, whose fault was it, huh?

Amy: Oh, wow, this is great. Wonderful. Back to square one. Well, what more can I say?

6) extensive (monologue): Finally, students at intermediate to advance levels are called on to give extended monologues in the form of oral reports, summaries, or perhaps short speeches.

\subsubsection{Techniques in Teaching Speaking}

In teaching speaking, teachers should be able to apply a suitable method and technique in class, so that the teaching learning can be successful and the students are able to speak well. In achieving goals in teaching, teacher has to use various tools of instructional.

Harmer (2007:348-353) states that there are some techniques in teaching speaking skill. They are:

1) discussion: A discussion can be held for various reasons. The students may aim to arrive at a conclusion, share ideas about an event, or find solutions in their discussion groups. Before the discussion, it is essential that the purpose of the discussion activity be set by the teacher.

2) story telling: Students can briefly summarize a tale or story they heard from somebody beforehand, or they may create their own stories to tell to their classmates. Story telling fosters creative thinking. It also helps students express ideas in the format of beginning, development, and ending, including the characters and setting a story.

3) dialogue: Dialogue helps the students practice in speech, pronunciation, intonation, and stress. The primary objective of using dialogue is developing students' competence (pronunciation, intonation, stress) in teaching speaking like native speaker. Therefore, in teaching learning using dialogue (short and long), the students are motivated by the teachers' question.

4) role play: One other way of getting students to speak is role-play. Students pretend they are in various social contexts and have a variety of social roles. In role-play activities, the teacher gives information to the learners such as who they are and what they think or feel.

5) debate: Teaching speaking can be done through debate technique. Debate can be implemented as the alternative way to teach speaking. The debate technique is a good technique to teach speaking. But without a good and interesting topic, it will be useless. Therefore, the English teacher must be selective in choosing the topic.

\subsection{Debate Technique}

According to Fedrizzi and Ellis (2008:4), debate is oral confrontation between two individuals, teams, or groups to argue reasons for and against a set position. These arguments follow a set form or procedure. Because debate is contentious by nature, we are expected to challenge our opponent's statements and to have our statements, opinions, and ideas challenged as well. Persuasion, which appeals to emotional responses, is a key element of the debate process.

Debate can be divided into two categories, namely informal and formal debate. Informal debate is a common occurrence with very little preparation or rules. It can take place anywhere. Examples of an informal debate are a group of friends deciding which movie to see or a child trying to persuade a parent to extend a curfew. In each case, there is an exchange of ideas for and against an issue between two or more people. Formal debates are quite different. They usually are scheduled and take place in a specified setting. People taking part in formal debates prepare extensively before the debates take place. The topic or resolution is established. But in this section, the writer will use formal debate. 


\subsubsection{Parts of Debate}

In the debate technical system, we will get some items which relate to the debate process. The following are some items related to debate:

1) motion: The topic debated is called a motion. Usually, motion started with word like "this house" (TH) or "this house believes that (THBT) or "this house believes (THB)" that refers to one group.

2) definition: Debaters should "down to earth" or see the current issue happened in society. Definition can be done in two ways, word by word definition or the global definition.

3 ) theme line: To agree or disagree towards a motion, the reason must lie on a strong ground that could cover the whole argumentation. Theme line is the underlying reason which answers the big question "why" one side of the house supports or opposes a motion.

4) argument: A debate is like a battle of argument, in which each team stands on their position, attacks the opposite and defends their own case. The praiseworthy jobs can be done well by using critical and logical thinking. Argument is the fragment of thought to support the theme line.

5) rebuttal: To win a debate, debaters not only need to build a strong case but they also have to attack their opponent's arguments and provide strong defense from any attack. That is why, rebuttal is one of the key to get the crown of victory. 6) sum-up/closing: Closing is simply concluding what has been done. A nice summary is preferable. Before starting the debate, debaters should know these parts of debate in order to be a good debater.

\subsubsection{Systems of Debate}

According to Mulgrave (2004:64-83), there are three systems of debate. They are:

1) Asian parliamentary debate: In the Asian parliamentary debate there are two teams. They are government team and opposition team. Each team consists of three members. The role of the government team is to support the motion. This involves defining the motion, constructing a positive case in favor of the motion, providing substantive materials and arguments in supporting of the case and responding to the challenges which made by the opposition team. The role of the opposition team is to negate the motion. This involves responding to the government's definition, constructing a case in opposition to the motion, providing substantive materials and arguments in supporting the case and responding the arguments delivered by the government.

2) Australasian parliamentary debate: Australasian parliamentary debate system consists of two teams, which debate over an issue, more commonly called a topic or proposition. The two teams in Australasian parliamentary debate are called the affirmative team and the negative team. The affirmative team agrees with the topic and presents arguments to demonstrate the truth of the topic. The negative team disagrees with the topic and presents arguments to disprove the truth of the topic.

3) British parliamentary debate: In British parliamentary debate, there are four teams two on each sides, they are: government and opposition. The teams are known as opening government, closing government, opening opposition and closing opposition. The general roles of the government and opposition teams are the same as those in Asian / Australasian format. The two teams on the same side have to work together in supporting the same general idea although they are from different team.

The writer used Australasian Parliamentary Debate, in order to improve students' speaking skill because this debate system is more suitable to be applied for Senior High School students.

\subsubsection{Procedures of Debate}

The form of debate was varied in use. In speaking classroom, was taken such the following procedures: 
1) dividing students into two teams,

2) selecting debate topic and assigning the two teams to debate the topic,

3 ) ensuring that the participants have time beforehand to prepare for the arguments and to collect supporting data to present during the debate,

4) presenting the topic and format of the debate,

5) an example format of the debate as following:

a) side 1 presents opening arguments, with three members each giving a statement,

b) side 2 presents opening arguments, with three members each giving a statement,

c) side 1 has chance for rebuttal,

d) side 2 has chance for rebuttal,

e) side 1 has chance for a second rebuttal,

f) side 2 has chance for a second rebuttal,

g) side 1 takes time for a conclusion,

h) side 2 takes time for a conclusion.

Debate usually consists of three members in every team, although sometimes four members in many debates. Debates are varied in use, sometimes it used based on the number of students in the classroom and the level of students.

\subsubsection{Strengths and Weaknesses of Debate}

According to Somjai (2015:28-29), every technique which is applied in process learning and teaching has strengths and weaknesses. It also happens in debate technique. Debate technique has a lot of strength. They are:

1) Training the students to cooperate well with other friends. In debating, students are trained to work in a team and hoped to have good cooperation each other.

2) Training the students to express their opinion. Opinion is badly needed in process of debating. Students are encouraged in expressing their opinion to defend their position.

3) Making the students take a role in debating, so they actively join the activity.

4) Improving the students' speaking skill. Speaking skill automatically improves when students practice debating, because they have a lot of opportunity in practicing speaking.

Although debate has strength in learning process, it has a lot of weaknesses too. The weaknesses are stated as follows:

1) Debate is only used for certain subject. Debate technique can only be used for specific subject, such as subject that related with agreeing and disagreeing and giving argument.

2) Debate needs long times and preparations. Many preparations are needed in debating in order to make debate run well. Students should prepare their arguments before debating to make them easier to attack the opponents.

3) Debate makes the students emotional in defending their argument. Many students cannot manage their emotion when they defend their argument.

Although it has these disadvantages, it seems that the benefits do outweigh the disadvantages in the development of English speaking. Moreover, its disadvantages can be minimized by the teachers.

\section{RESEARCH METHOD}

\subsection{Research Design}

The research was conducted by applying Classroom Action Research (CAR). Kemmis as quoted by Hopkins (1993:44) states "Action research is a form of self- reflective inquiry undertaken by participants in a social situation (including education) and justice of their own social or educational practice, their understanding these of practices, and the situation in which practices are carried out". In other words, action research is defined as the study of a social situation with a view to improve the quality of action within it. While, Mills (2000:6) states that action research is any systematic inquiry conducted by teachers, researchers, principals, school 
counselors, or other stakeholders in teaching learning environment to gather information about the ways how their particular school operate, how they teach, and how well their students learn.

From the definitions above, the researcher concluded that classroom action research is an action research in a classroom which can be done by teachers, researchers, and teachers with their colleagues, etc which involves a group of students to improve teaching and learning process or to enhance the understanding of the students to the lesson.

In this classroom action research, the researcher collected the data by using qualitative and quantitative methods. Wallace (1978:38) defines that qualitative method is used to describe data which cannot be counted or measured in an objective way, while quantitative method is broadly used to describe what can be counted or measured.

\subsection{The Location, Subject and Time of the Research}

This research was conducted at SMK Swasta Dharma Bakti Medan. It is located at Jl. Letjen Jamin Ginting, Km. 8 Kuala Bekala Padang Bulan Kecamatan Medan Johor, Medan, and this school has been operating since 1987. The subject of this research is the eleventh grade students of Accounting Section Class XI A of SMK Swasta Dharma Bakti, Medan. The numbers of students in that class are 27 students. This study was conducted at the beginning of September 2016.

\subsection{The Instrument for Collecting Data}

Instruments were used in collecting data of this research were:

\section{Quantitative Data}

Spoken test was used to assess the students' speaking skill.

\section{Qualitative Data}

There were two instruments that used in this qualitative data. They were:

\section{a. Observation Sheet}

Observation sheet was used to identify all conditions that happened during the teaching learning process including the teachers, students and situation in the class.

\section{b. Diary Notes}

Diary notes were used to investigate the situation and the problems found during teaching learning process. In this data collection, the writer also needed a collaborator. A collaborator in classroom action research is person who helps the researcher to collect the data. The collaborator in this research was the teacher of English who teaches at the eleventh grade students of Accounting Section Class XI A of SMK Swasta Dharma Bakti, Medan. He is Mr. U. Barus.

\subsection{The Techniques in Analyzing the Data}

In this research, the writer used qualitative and quantitative data. As explained before, the qualitative data were taken from the observation sheet and diary notes which were used to describe the situation during the teaching learning process. While the quantitative data was taken from the students' spoken test scores which was used to analyze the improvement of the students' speaking skill in each cycle.

Here was the grading rubric for debate, which was used to see the students' activeness when the debate technique was introduced. 
Table 3.1 Scoring Guidance for Debate

\begin{tabular}{|c|c|c|c|}
\hline $\mathrm{NO}$ & $\begin{array}{l}\text { Aspects of } \\
\text { Assessment }\end{array}$ & Score & Description \\
\hline 1. & Pronunciation & $\begin{array}{l}17-20 \\
13-16 \\
9-12 \\
5-8 \\
1-4\end{array}$ & $\begin{array}{l}\text { Have few traces of foreign accent. } \\
\text { Always intelligible, though one is conscious of a } \\
\text { definite accent. } \\
\text { Pronunciation problems necessitate concentrated } \\
\text { listening and occasionally lead to } \\
\text { misunderstanding. } \\
\text { Very hard to understand because of pronunciation } \\
\text { problems. Must frequently be repeated. } \\
\text { Pronunciation problems to severe as to make speech } \\
\text { virtually un intelligible. }\end{array}$ \\
\hline 2. & Grammar & $\begin{array}{l}17-20 \\
13-16 \\
9-12 \\
1-4\end{array}$ & $\begin{array}{l}\text { Makes few (if any) noticeable errors of grammar or } \\
\text { word order. } \\
\text { Occasionally makes grammatical and word order } \\
\text { errors which do not, however, obscure meaning. } \\
\text { Makes frequent errors of grammar and word order } \\
\text { which occasionally obscure meaning. } \\
\text { Grammar and word order errors make } \\
\text { comprehension difficult. Must often rephrase } \\
\text { sentences and / or restrict himself to basic patterns. } \\
\text { Errors in grammar and word order so severe as to } \\
\text { make speech virtually unintelligible. }\end{array}$ \\
\hline 3. & Vocabulary & $\begin{array}{r}17-20 \\
13-16 \\
9-12\end{array}$ & $\begin{array}{l}\text { Use of vocabulary and idiom is virtually that of } \\
\text { native speaker. } \\
\text { Sometimes uses un appropriate terms and/ or } \\
\text { rephrase ideas because of lexical inadequacies. } \\
\text { Frequently uses the wrong words, conversation } \\
\text { somewhat limited because of inadequate } \\
\text { vocabulary. } \\
\text { Misuse of words and very limited vocabulary make } \\
\text { comprehension quite difficult. } \\
\text { Vocabulary limitations so extreme as to make } \\
\text { conversation virtually impossible. }\end{array}$ \\
\hline
\end{tabular}


KAIROS ELT JOURNAL, Vol. 1, No. 2, August 2017

Copyright@2017, ISSN: 2580-4278

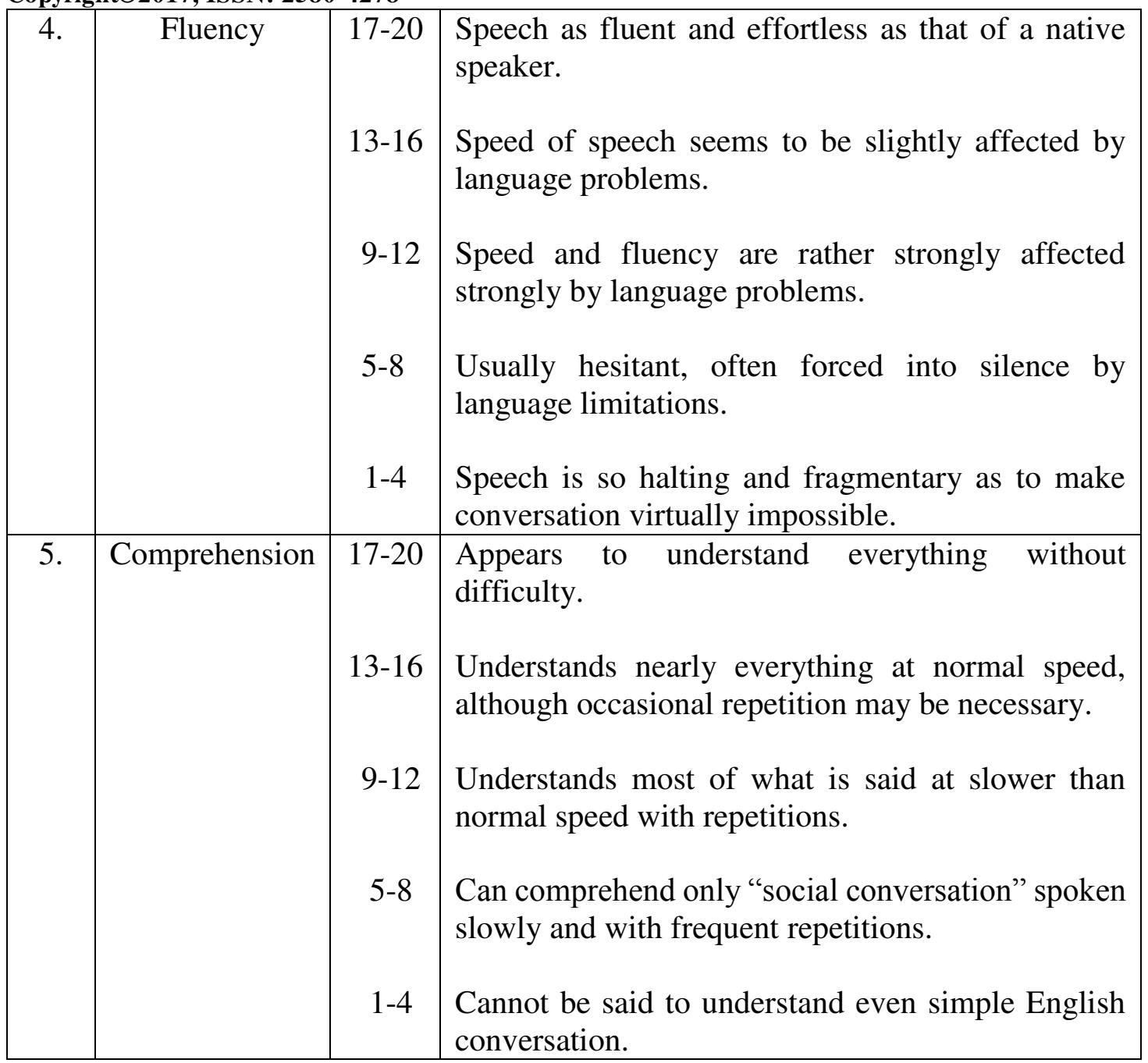

Table 3.2 The Score Analytic

The score analytic is like below:

\begin{tabular}{|c|c|}
\hline Score & Grade \\
\hline $17-20$ & Excellent \\
\hline $13-16$ & Good \\
\hline $9-12$ & Fair \\
\hline $5-8$ & Poor \\
\hline $1-4$ & Very bad \\
\hline
\end{tabular}

Then, the result of observation was analyzed such as below (Best and James: 2002:34):

$$
\overline{\bar{X}}=\frac{\sum x}{\mathrm{~N}} x 100 \%
$$

Explanation:

$$
\begin{array}{ll}
\overline{\mathrm{X}} & =\text { the mean of the students' score } \\
\sum x & =\text { the total score } \\
\mathrm{N} & =\text { the number of the students }
\end{array}
$$

The writer got score from the two cycles conducted in the research. Mean of score from the first cycle was compared with the mean of the second cycle. It was to know how far the progress of students in this research.

Next, to categorize the number of students who passed the test successfully, the writer applied the following formula:

$$
P=\frac{R}{T} \times 100 \%
$$


Explanation:

$\mathrm{P} \quad=$ the percentage of students who get point 70

$\mathrm{R}=$ the number of students who get point 70

$\mathrm{T}=$ the total number of students who take the test

\subsection{Procedures of Classroom Action Research}

In this action research, the writer used the model developed by Kemmis and McTaggart (in Burns, 1999:32). There are four components in one cycle for conducting classroom action research. It consists of planning, action, observation, and reflection. The four phases of the classroom action cycle was integratedly conducted like spiral. Each phase was concluded based on the previous one and the next. It meant that the activities in the classroom action research were based on planning, action, and observation, then, the researcher made a reflection to determine the next cycle.

Figure 1

The Steps of Action Research
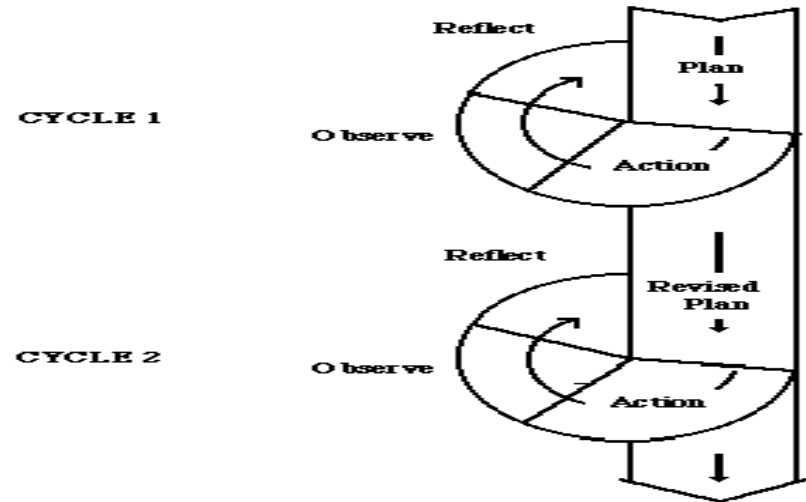

Before conducting the cycle in action, the writer did an initial observation at first. Then she did some procedures and steps as follows:

1) Pre-cycle

In pre-cycle the writer was intended to know the initial condition of students. The writer observed students' activity in speaking class. Based on the observation the writer knew the problem that happened to the students and their difficulties in speaking.

2) Cycle 1

The writer used debate technique in teaching speaking. The topic was expressing agreement and disagreement. The procedures as follows:

a) Planning

Planning an action research by focusing on who, what, when, where, and how the action was done. It includes, arranging lesson plan, preparing the media related to the material, preparing teaching material, preparing checklist observation, and making the test material.

b) Action

The planning strategy was applied in teaching learning process. The actions were, explaining the material, introducing debate technique to the students, and asking students to make group and conducting debate based on the topic given.

c) Observation

The observation was done to check the students' activities in debate, the students' responses during the teaching and learning process, and the students' speaking skill improvement. 


\section{d) Reflecting}

In this step, the writer analyzed the whole action that has been done. Based on the data that has been collected, the teacher and the writer discussed and made evaluation to determine the next cycle. It meant if there was no improvement in cycle one, the writer has to do the second cycle in order to achieve the improvement that the writer has planned.

3) Cycle 2

a) Planning

1) Identifying the problem and making the solution for the problem,

2) Arranging lesson plan,

3) Preparing the media related to the material,

4) Preparing teaching material,

5) Preparing checklist observation,

6) Making the test material.

b) Action

1) Teacher explained the material,

2) Teacher introduced debate technique to the students,

3) Teacher asked students to make group and conducted debate based on the topic given.

c) Observation

The observation was done to check:

1) The students' activities in debate,

2) The students' responses during the teaching and learning process,

3) The students' speaking skill improvement.

d) Reflecting

In this step, the writer analyzed the whole action that has been done. Based on the data that has been collected, the teacher and the writer discussed and made evaluation.

\section{RESEARCH FINDINGS AND DISCUSSION \\ 4.1 Research Findings}

The findings of this research showed that debate technique could improve students' speaking skill. The improvement could be seen from the students' mean score from the pre-test up to post-test II. The students' mean score in pre-test was 66.2, the mean formative test cycle I was 67.6, and the mean of post-test cycle II was 76.3. The qualitative data also showed that students became more active, enthusiastic, enjoyable, and more eager in practicing their speaking.

\subsection{Discussion}

Debate technique was applied to improve students' speaking skill to the eleventh grade students of Accounting Section Class XI A of SMK Swasta Dharma Bakti Medan. Before applying the debate technique in teaching speaking, most of the students were lazy to practice their speaking. The writer analyzed that most of the students did not pay attention to their teacher. Even, when the writer did the pre-test, the students' score was so bad. Only 9 students of 27 students passed the KKM.

After applying debate technique, the students became more active in practicing their speaking. The students' mean score in formative cycle I improved. After finishing cycle I, the writer did the cycle II, and the result showed that students' score also improved. Thus, from the result it could be said that debate technique could improve students' speaking skill successfully.

But in applying this technique, the writer faced some problems. Some problems that faced by the writer for example, the number of the students, because there were so many students in that class, so, when the writer tried to approach some students, other students made noise. Thus, the writer faced difficulty in managing them. 
The next problem was the background of their knowledge. Although every student had different background of knowledge, but almost all of the students in that class were not so clever. But nevertheless, the writer could apply this technique well because the students had willingness to study, they were also so active in asking some questions, and also because the writer had a collaborator that helped her in doing the actions. The writer should often motivate them to study English because this language plays an important role in the global world. It is understandable that they have no good motivation in learning since they are still immature.

\section{CONCLUSIONS AND SUGGESTIONS}

\subsection{Conclusions}

The conclusions of this research are presented according to the data which have been analyzed in the previous chapter. From all the data analysis about using debate technique to improve students' speaking skill (A Classroom Action Research to the Eleventh grade Students of Accounting Section Class XI A of SMK Swasta Dharma Bakti Medan in the Academic Year of 2016/2017), it can be concluded that:

1) The use of debate technique has advocated the process in teaching speaking. Debate is very interesting to be implemented to improve speaking skill. Students have a lot of opportunities to practice speaking and have active involvement in debate. In addition, they work very cooperative and try to defend their team, and they are more active to speak in classroom.

2) Teaching speaking through debate can be enjoyable experience for both teacher and students. Students can improve their speaking skill after being taught by debate technique. It can be seen by students' achievement in speaking test in each test. In the pre-test the average of the students' achievement is 66.2. While in the formative test cycle I, the average of the students' achievement is 67.6 , and in the post-test cycle II, the average of the students' achievement is 76.3. Students' speaking skill increased and they are interested in speaking through debate. The result of the research shows that the students improve their speaking skill efficiently and effectively.

\subsection{Suggestions}

In the teaching and learning of English language, a teacher must create enjoyment, fun and interesting situation as far as possible. The enjoyment ought to be the foremost aims which hopefully will have good effects on education. On the other hand, the teacher has to make the learning as attractive as possible, so that the students enjoy the learning well. Teaching speaking through debate technique can motivate students to practice speaking more, and it improves students' speaking skill. The writer suggests the teacher uses this technique because it encourages students in speaking.

It is also recommended to those who are interested in conducting research especially about speaking, to employ this technique for the purpose of strengthening it. However, it is not only limited to this technique but it is also open to use other techniques as far as it can improve the students' speaking skill.

\section{BIBLIOGRAPHY}

Best, John W. and James V. Kahn. 2002. Research in Education ( $7^{\text {th }}$ Ed). New Delhi: Prentice Hall of India.

Brown, Douglas. 2001. Teaching by Principles: An Interactive Approach to Language Pedagogy. Englewood Cliffs, NJ: Prentice Hall Regents. 
Burns, Anne. 1999. Collaborative Action Research for English Language Teachers. Cambridge: Cambridge University Press.

Fedrizzi, Mariann and Ellis, Randy. 2008. Debate. Cambridge: Cambridge University Press.

Fulcher, Gleen. 2003. Testing Second Language Speaking. New York: Pearson Longman.

Harmer, Jeremy. 2007. The Practice of English Language Teaching. New York: Pearson Longman.

Hery, John. 2011. Improving Students' Speaking Skill through Debate Technique. Thesis, Faculty of Languages and Arts: State University of Medan. Unpublished.

Hopkins, David. 1993. A Teacher's Guide to Classroom Research. Buckingham: Open University Press.

Mills, Geoffrey E. 2000. A Teacher's Guide to Classroom Research. Buckingham: Open University Press.

Mulgrave, Dorothy. 2004. Speech: A Handbook of Voice Training Diction and Public Speaking. New York: Hagerstown.

Rubiati, Richa. 2010. Improving Students'Speaking Skill through Debate Technique. Thesis, Teachers Training and Education Faculty: State University of Semarang. Unpublished.

Somjai, Satit. 2015. "The Use of Debate Technique to Develop Speaking Ability". International Journal of Technical Research and Applications, 5(2), 27-31.

Wallace, Michael J. 1978. Action Research for Language Teachers. Cambridge: Cambridge University Press. 